Volume 1, Nomor 2, Maret 2021, Hal 88-94

BEMAS: JURNAL BERMASYARAKAT

p ISSN 27455866 | e ISSN 27457958

\title{
PELATIHAN PENYUSUNAN MODUL GUNA MENINGKATKAN KUALITAS LITERASI BAGI GURU SMA NEGERI 4 PURWOKERTO
}

\author{
Uki Hares Yulianti $^{1 *}$, Nadia Gitya Yulianita ${ }^{2}$, Nisa Roiyasa ${ }^{3}$ \\ 1,2,3 Fakultas Ilmu Budaya, Universitas Jenderal Soedirman, Purwokerto, Indonesia \\ Email:*ukihares@unsoed.ac.id,nadiagityay@unsoed.ac.id,nroiyasa@unsoed.ac.id
}

\author{
INFORMASI ARTIKEL \\ Article History: \\ Submission: 26-11-2020 \\ Revised: 10-03-2021 \\ Accepted: 18-03-2021 \\ * Korespondensi: \\ Uki Hares Yulianti \\ ukihares@unsoed.ac.id
}

\begin{abstract}
ABSTRAK
Modul merupakan bahan ajar yang dapat digunakan oleh guru dalam memberikan materi selama pembelajaran. Selain itu, modul merupakan salah satu syarat bagi guru untuk dapat mengajukan kenaikan pangkat. Meskipun demikian, masih banyak guru yang tidak dapat menyusun modul untuk membantu mereka dalam mengajar dan mengembangkan potensi diri. Oleh sebab itu, kegiatan pendampingan penulisan modul bagi guru SMA Negeri 4 Purwokerto ini akan memberikan keuntungan bagi guru dan siswa. Guru akan dapat mengajar baik dengan bahan ajar yang ada dan mendapat poin untuk kenaikan pangkat, dan siswa mendapatkan materi yang terstruktur dan sistematis. Metode yang digunakan dalam kegiatan pengabdian kepada masyarakat ini adalah active and participatory learning yang meliputi ceramah, diskusi, dan konsultasi. Ceramah dan diskusi dilakukan untuk memberikan penjelasan mengenai modul pembelajaran secara umum, sedangkan konsultasi dilakukan untuk pendampingan pembuatan modul yang dilakukan oleh guru dan narasumber. Dampak dari pendampingan modul di SMA Negeri 4 Purwokerto ini berdampak baik bagi guru. Hal ini ditunjukkan dari modul yang dihasilkan guru sudah disesuaikan dengan kebutuhan peserta didik. Selain itu, guru juga memiliki bahan ajar yang baik untuk penyampaian materi dan siswa dapat menguasai materi yang diberikan dengan baik.
\end{abstract}

Kata Kunci: Pelatihan, modul, guru

TRAINING ON MODULE DEVELOPMENT TO IMPROVE LITERATION QUALITY FOR TEACHERS OF SMA NEGERI 4 PURWOKERTO

ABSTRACT
Module is a learning media used by teachers to teach during the
learning process. Besides, modules produced by teachers are one of the
requirements to apply for promotion. However, there are still many
teachers who do not know how to write a module to help them teach and
improve their potential. Therefore, this module-writing workshop would
be beneficial for teachers and students. Teachers could use this module
to teach well and get points required for promotion, while students could
get structured and systematic materials. The method used in this
community service was active and participatory learning: lectures,
discussion, and consultation. Lecture and discussion were applied to
give explanations about the learning module, while consultation was
done to assist the teachers in writing their modules. This module making
assistance at SMA Negeri 4 Purwokerto has good impacts on teachers.
This is indicated by the modules produced by the teachers have been
adjusted to the students' needs. In addition, the teachers can have good
teaching materials to be delivered to the students and the students can


master the materials well.

Keywords: Training, modules, teachers

\section{PENDAHULUAN}

Pada abad ke-21 tantangan era pengetahuan yang semakin berkembang memerlukan sumber daya manusia dengan keterampilan intelektual tingkat tinggi. Keterampilan intelektual tinggi ditandai dengan kemampuan penalaran yang logis, sistematis, kritis, cermat, dan kreatif serta memiliki sikap yang baik dalam mengkomunikasikan gagasan dan memecahkan masalah[1]. Salah satu keterampilan intelektual tinggi adalah kemampuan berpikir kritis untuk menghadapi dunia pendidikan[2].

Kemampuan berpikir kritis berperan penting dalam membekali siswa dalam menangani masalah sosial, ilmiah, dan praktis secara efektif di masa mendatang[3]. Observasi dan wawancara telah dilakukan ke sekolah untuk mengetahui hasil berpikir kritis pada siswa[4]. Dari hasil tersebut diketahui kemampuan berpikir kritis siswa memang masih kurang. Hal ini dibuktikan dalam proses kegiatan belajar mengajar, yaitu 1) keaktifan siswa dalam tanya jawab, 2) siswa belum mampu memecahkan suatu masalah yang disajikan guru, 3) siswa masih sedikit yang dapat mampu menjawab soal berkategori soal HOTS, 4) siswa belum mampu menganalisis suatu masalah, dan 5) siswa dan guru menggunakan modul dan buku ajar yang berasal dari pasaran.

Dari hasil observasi tersebut diketahui memang masih banyak guru yang menggunakan modul, buku ajar, dll yang ada di pasaran. Guru belum berusaha untuk menyusun bahan ajar sendiri untuk kepentingan proses belajar mengajar[5]. Salah satu jenis bahan ajar adalah modul yang merupakan salah satu program belajar mengajar yang terkecil. Modul pembelajaran juga merupakan salah satu jenis bahan ajar yang disusun sistematis dan menarik baik dari segi isi materi, metode, dan evaluasi yang dapat digunakan secara mandiri[6]. Modul pembelajaran yang baik juga harus memiliki karakteristik, seperti memberikan contoh dan ilustrasi yang mendukung topik pembahasan, memakai Bahasa yang komunikatif, memiliki rangkuman materi dan penilaian yang dapat digunakan untuk mengukur dan mengevaluasi tingkat penguasaan materi[7].

PP nomor 19 tahun 2005 Pasal 20, mengisyaratkan agar guru mampu mengembangkan materi pembelajaran[8]. Pengembangan bahan ajar memang sangat diperlukan dan harus sesuai dengan tuntutan kurikulum[9]. Modul yang merupakan bagian dari bahan ajar dalam pengembangannya juga harus sesuai dengan tuntutan kurikulum 2013 yang bisa membuat siswa memiliki kemampuan berpikir kritis[10]. Modul diserahkan sepenuhnya kepada guru untuk menyusunnya. Guru diharapkan dapat menyusun modul sendiri untuk keperluan anak didiknya. Hal ini tentu akan lebih baik karena yang lebih paham tentang karakteristik anak didik, lingkungan belajar anak didiknya adalah gurunya sendiri[11].

\section{METODE}

Kegiatan pengabdian ini dilaksanakan selama 30 hari, yang berlangsung sejak tanggal 5 Agustus 2020 sampai dengan 5 September 2020. Kegiatan ini bertempat di SMA Negeri 4 Purwokerto. Kegiatan bimbingan belajar ini memiliki target, adapun target yang ingin dicapai dari kegiatan ini adalah meningkatkan motivasi guru untuk membuat modul pembelajaran yang sesuai dengan kurikulum 2013 dan mampu mengakomodasi kebutuhan para siswa.

Metode pelaksanaan pengabdian masyarakat pada kegiatan ini adalah ceramah, diskusi, dan konsultasi terkait dengan pelatihan pembuatan modul guna meningkatkan kualitas literasi bagi guru SMA Negeri 4 Purwokerto. Ceramah dilakukan oleh narasumber untuk memberikan materi penyusunan modul. Setelah ceramah, narasumber dan para guru melakukan diskusi dan tanya jawab 
Pelatihan Penyusunan Modul Guna Meningkatkan Kualitas Literasi Bagi Guru SMA

Negeri 4 Purwokerto

mengenai penyusunan modul. Setelah itu, para guru menkonsultasikan modul yang telah mereka buat kepada narasumber. Dengan demikian, para guru dapat memiliki modul pembelajaran yang dapat mereka gunakan untuk mengajar.

\section{HASIL DAN PEMBAHASAN}

\subsection{Hasil.}

Pelatihan penyusunan modul bagi guru pada kesempatan kali ini dilakukan secara daring karena kondisi yang sedang mengalami pandemic covid-19. Sesuai kesepakatan dengan mitra sekolah SMA Negeri 4 Purwokerto pelatihan dilakukan secara daring melalui zoom. Narasumber berada di lokasi yang berbeda, ada yang di FIB Unsoed, dan rumah, sedangkan para guru yang mengikuti pelatihan dari laboratorium SMA Negeri 4 Purwokerto.

Pelatihan penyusunan modul guna meningkatkan kualitas literasi bagi guru yang dilaksanakan di SMA Negeri 4 Purwokerto, pada hari Rabu, 5 Agustus 2020 yang diikuti oleh 20 peserta. Para guru di sana menyambut dengan antusias, Tim Pengabdi datang, para guru sudah siap memberikan arti bahwa pelatihan penyusunan modul sungguh berarti bagi mereka. Kegiatan dimulai tepat pukul 10.00 WIB. Acara dibuka oleh Wakil Kepala Sekolah SMA Negeri 4 Purwokerto, Tri Anggara, S.Pd., kemudian diserahkan sepenuhnya kepada Tim Pengabdi.

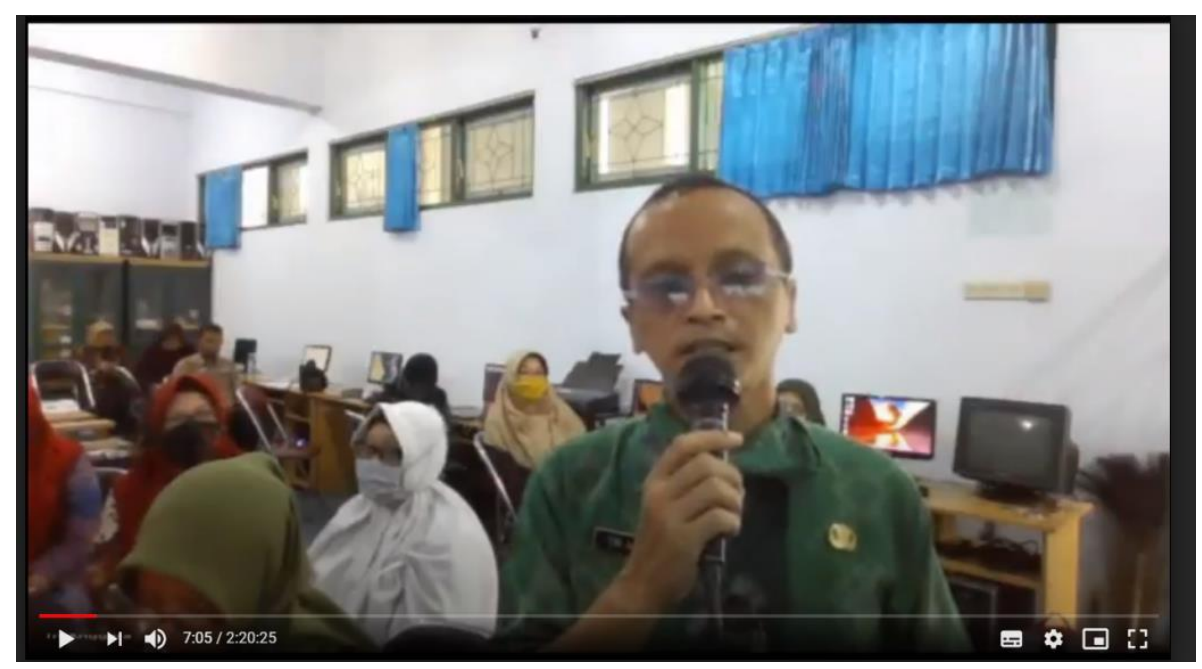

Gambar 1. Pembukaan pelatihan modul oleh Wakil Kepala Sekolah secara daring.

Penyampaian materi dilakukan dengan desain Project Based Learning. Project Based Learning adalah metode pembelajaran yang didasari oleh proyek tertentu. Dalam konteks kegiatan pengabdian ini, proyek utamanya adalah penyusunan modul bagi guru. Artinya, setiap guru yang mengikuti kegiatan pengabdian ini akan menyusun sebuah modul. Adapun tahap penyampaian materi dilakukan dengan cara dijelaskan oleh pakar di bidang penyusunan modul bagi guru, dan pembimbingan penyusunan modul [12]. Penjelasan dilakukan dengan ceramah kreatif dikombinasikan dengan contoh, contoh kasus, dan lain sebagainya. Dalam pelaksanaannya, pelatihan dilaksanakan dengan 2 cara yaitu:

A. Metode ceramah.

Tim pengabdi menggunakan metode ceramah dengan bantuan Power point. Menjelaskan materi penyusunan modul guna meningkatkan kualitas literasi bagi guru secara rinci yang meliputi: karakteristik modul; prinsip pengembangan modul, analisis kebutuhan modul, Langkah-langkah penyusunan modul, desain modul, evaluasi dan penilaian modul. Para guru diberikan deskripsi mengenai kelebihan dan kekurangan dalam penyusunan modul [13]. Perbedaan mengenai modul dan 
diktat juga diinformasikan kepada peserta karena banyak guru yang belum memahami betul adanya perbedaan antara diktat dan modul. Dalam presentasi, diberikan alasan penyusunan modul yang sangat berguna untuk meningkatkan kualitas literasi dan sebagai salah satu hasil karya tulis ilmiah yang dihasilkan. Kendala yang dihadapi dalam proses penjelasan teori ini adalah tidak stabilnya jaringan wifi tiap guru sehingga beberapa kali tatap muka secara daring sempat terhenti. Oleh karena itu, guru memerlukan pengarahan yang telaten dan dekat agar bisa lebih paham proses penyusunan modul.

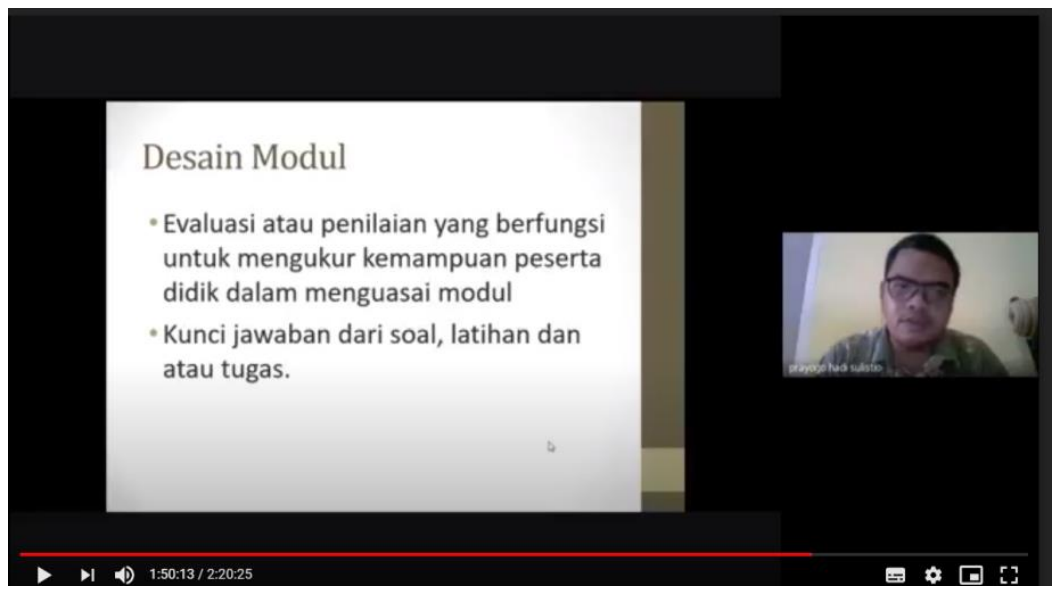

Gambar 2. Pemberian teori penyusunan modul secara daring.

B. Drill practice atau latihan praktik.

Setelah penjelasan materi selesai, untuk pendalaman materi sekaligus mengaplikasikan antara teori dengan kenyataan, guru-guru diminta untuk mempraktikkan apa yang sudah disampaikan dengan berlatih menyusun modul.

Pelatihan penyusunan modul guna meningkatkan kualitas literasi bagi guru yang semula direncanakan untuk melakukan praktik langsung ternyata tidak dapat dilakukan secara maksimal karena keterbatasan waktu. Oleh karena itu, dilanjutkan di lain hari untuk praktik penyusunan modul secara menyeluruh. Selain itu, para guru yang sudah memulai praktik penyusunan modul guna meningkatkan kualitas literasi bagi guru bisa konsultasi melalui Whatsapp grup yang sudah dibuat atau melalui email. Sehingga di pertemuan selanjutnya waktu yang digunakan bisa lebih efektif.

Pelaksanaan pelatihan penyusunan modul guna meningkatkan kualitas literasi bagi guru, dipandang penting mengikutsertakan semua guru sebagai panitia sekaligus peserta, meskipun belum mampu merekrut lebih banyak. Paling tidak dengan adanya banyak guru dari berbagai mata pelajaran yang ikut menangani baik langsung maupun tidak, akan mempermudah pelaksanaan kegiatan.

Kesulitan yang paling mendasar dialami oleh guru-guru di SMA Negeri 4 Purwokerto adalah menyusun modul yang tepat dan efisien. Hal ini disebabkan oleh mereka tidak terbiasa menulis. Modul merupakan salah satu jenis karya tulis ilmiah yang baik akan dilahirkan. Kebanyakan guruguru sudah mampu membuat karya ilmiah, tetapi bukan dalam bentuk modul. Guru-guru lebih banyak menulis hasil dari penelitian tindakan kelas yang mereka lakukan. Hal yang dilakukan oleh guru-guru adalah menghasilkan karya ilmiah yang dianggap mudah dan dapat digunakan untuk kenaikan pangkat. Kualitas laporan penelitian yang dibuat juga tergolong kurang. Akibatnya, kualitas karya ilmiah yang dihasilkan juga kurang maksimal. Padahal penyusunan modul memiliki manfaat yang tidak hanya bisa digunakan sebagai kenaikan pangkat dalam pembuatan karya tulis ilmiah, akan tetapi modul juga bisa digunakan untuk pedoman dalam mengajar. Bahkan modul bisa dikembangkan menjadi sebuah buku yang bisa diperbanyak dan disebarluaskan dalam proses pembelajaran.

Selama kegiatan penyusunan modul guna meningkatkan kualitas literasi bagi guru di rumah masing-masing, ada beberapa guru yang memanfaatkan kegiatan konsultasi melalui Whatsapp grup 
yang sudah dibuat atau melalui email. Para guru begitu antusias saat diadakan pembimbingan, mereka memanfaatkan kegiatan konsultasi pada waktu yang sudah ditentukan, yaitu pada tanggal 5-31 Agustus 2020.

\subsection{Pembahasan.}

Sebagaimana dijelaskan di atas, pelatihan penyusunan modul guna meningkatkan kualitas literasi bagi guru ini dibagi menjadi tahap pembelajaran dan latihan. Sasaran pelatihan ini adalah bagaimana guru-guru paham mengenai modul dan manfaatnya untuk guru itu sendiri. Para guru diajarkan bagaimana menyusun modul yang benar. Dimulai dengan karakteristik modul; prinsip pengembangan modul, analisis kebutuhan modul, langkah-langkah penyusunan modul, desain modul, evaluasi dan penilaian modul [14].

Secara kualitatif, dapat disimpulkan bahwa kegiatan ini berlangsung dengan baik. Hal ini didasarkan pada pengamatan selama proses berlangsung. Apa yang teramati adalah bahwa para peserta mengikuti kegiatan dengan serius tapi santai serta penuh semangat. Selama proses berlangsung, para peserta bertanya banyak hal yang berkaitan dengan proses penyusunan modul. Semua peserta tetap mengikuti seluruh proses pelatihan sampai kegiatan berakhir. Hampir tidak ada halangan yang berarti selama penyelenggaraan kegiatan ini. Kegiatan dimulai tepat waktu pukul 10.00 tapi berakhir 1 jam lebih lama dari waktu yang direncanakan karena para peserta antusias bertanya mengenai penyusunan modul.

Pada kegiatan pendampingan terlihat guru belum menguasai penyusunan modul. Pada sesi tanya jawab, banyak pertanyaan yang diajukan mengenai: 1. Langkah-langkah penyusunan modul, 2. Modul yang baik sesuai kebutuhan peserta didik, dan 3. Syarat-syarat yang harus ada di modul. Dari pertanyaan yang diajukan inilah, akhirnya guru mendapatkan materi yang cukup sebagai bekal penyusunan modul.

Selama proses penyusunan modul juga dilakukan penyebaran angket mengenai pelatihan ini. Pertanyaan yang diajukan mengenai apakah peserta sebelumnya sudah ada yang membuat modul, didapatkan hasil hanya 5\% yang sudah pernah membuat modul. Akan tetapi, modul yang dibuat pun belum selesai karena kekurangtahuan penyusunan modul yang benar. Didapatkan pula hasil $85 \%$ peserta pelatihan yang siap menerima pelatihan penyusunan modul. Sebanyak $95 \%$ peserta pelatihan mengharapkan adanya pembimbingan pelatihan penyusunan modul yang dilakukan secara berkala. Peserta pelatihan penyusunan modul sebanyak 30\% siap menyelesaikan modul selama satu bulan selama proses pembimbingan. Sebanyak $70 \%$ peserta pelatihan juga berharap pembimbingan pelatihan penyusunan modul dilakukan secara luring.

Setelah dilakukan pelatihan penyusunan modul, para guru peserta pelatihan diminta untuk mengisi kuisioner yang disediakan dengan penilaian skala Likert Dimana skala Likert yaitu dengan rentang nilai 1 untuk penilaian rendah atau sangat tidak puas hingga nilai 5 untuk penilaian tinggi atau sangat puas [15]. Poin penilaian yang didapatkan dari para guru kemudian dihitung reratanya dan dari situ bisa ditentukan tingkat kepuasan para guru dengan skala 0-5, yaitu sangat tidak puas (nilai rerata $0-1.25)$, tidak puas (1.25-2.5), puas (2.5-3.75) dan sangat puas (3.75-5). Ada 15 orang guru atau $75 \%$ dari jumlah peserta pelatihan, yang mengisi kuisioner evaluasi. Dari hasil kuesioner diketahui pelatihan penyusunan modul membuat para guru tertarik menyusun modul sebagai bahan ajar yang digunakan (dengan nilai 4.33). Penyusunan modul juga dirasa pembuatannya memang memerlukan waktu yang cukup banyak (dengan nilai 3.33) tetapi dirasa sangat membantu tugas mengajar para guru jika modul sudah jadi (dengan nilai 4.5). Sebanyak 10 dari 15 guru (atau 66,7\%) yang dievaluasi menyatakan telah berlatih menyusun modul sebagai bahan ajar yang digunakan walaupun banyak yang belum selesai. Berikut ini adalah contoh modul yang telah dibuat oleh guru peserta pelatihan penyusunan modul. 


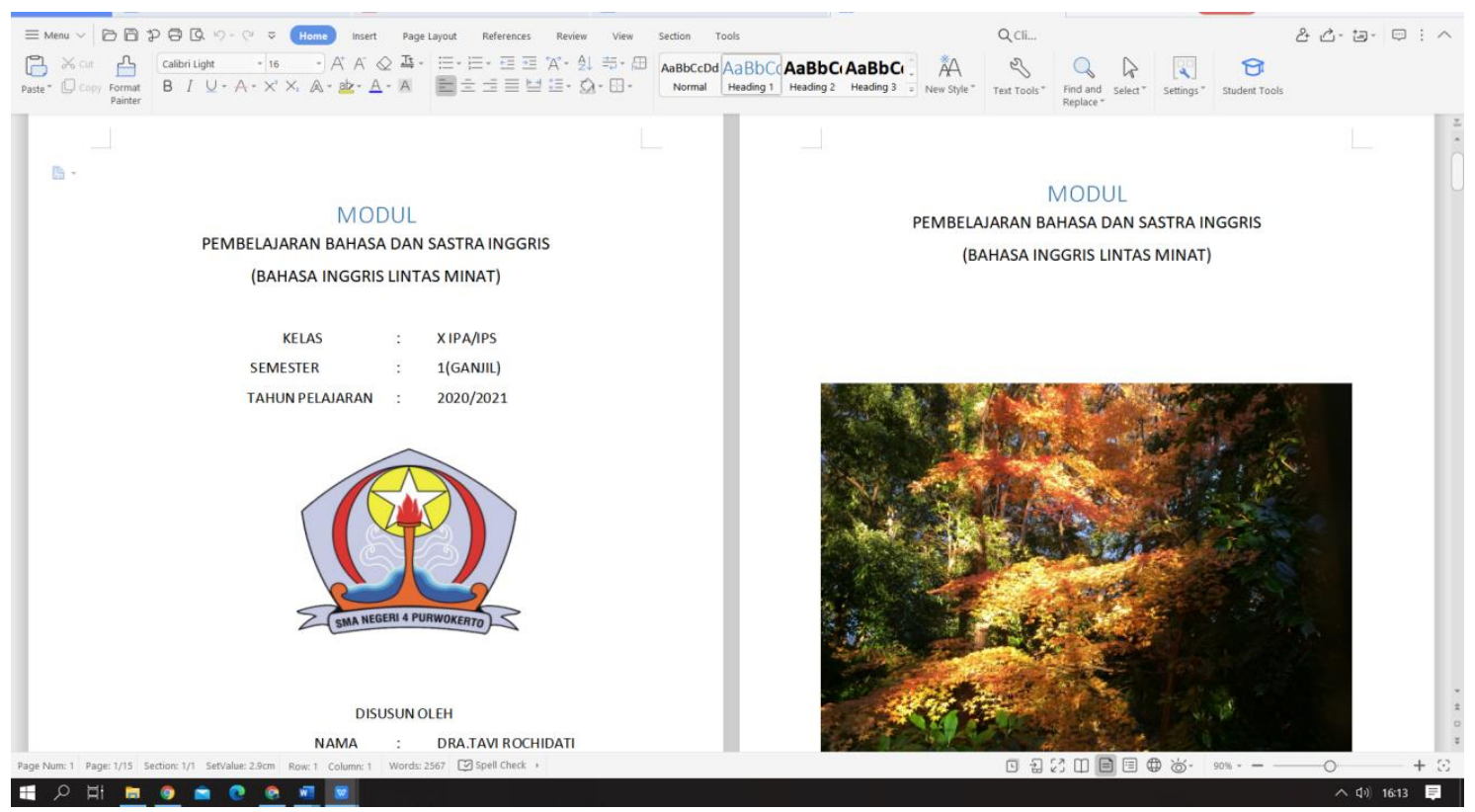

Gambar 3. Modul yang dihasilkan oleh peserta pelatihan penyusunan modul.

Pelatihan penyusunan modul guna meningkatkan kualitas literasi bagi guru yang dilaksanakan pada guru-guru di SMA Negeri 4 Purwokerto ini secara umum dapat dikatakan berhasil, yakni berdasarkan evaluasi sementara yang dilakukan secara seksama, baik dalam evaluasi materi maupun evaluasi kemanfaatan. Dalam evaluasi materi, meskipun tidak semua peserta melakukan praktik, namun dari perwakilan yang menyusun modul terlihat sudah mulai bisa menuangkan gagasannya.

Ditinjau dari sisi jumlah pesertanya, yakni yang semula hanya direncanakan sekitar 15 orang dan pada pelaksanaannya mencapai 20 orang, tampak bahwa guru-guru di masih sangat perlu mendapatkan pengembangan pelatihan. Hal itu tentu saja tidak hanya secara kuantitatif, karena secara kualitatif pun, mereka sangat antusias mulai dari awal pelaksanaan dengan mendengarkan ceramah, ikut aktif dalam tanya jawab, hingga pada praktik penyusunan modul. Dari 20 peserta yang mengikuti pendampingan penyusunan modul juga menghasilkan sebanyak 18 modul yang dihasilkan.

Sebelum penutupan, ketika peserta penyusunan modul guna meningkatkan kualitas literasi bagi guru diberi pertanyaan apakah mereka mendapatkan pengetahuan dan pengalaman baru mengenai penyusunan modul, mereka secara serentak menjawab, ya. Artinya, mereka sepakat bahwa evaluasi secara kemanfaatan, mereka telah mendapatkan pengetahuan dan pengalaman baru dalam Menyusun modul. Ketika sesi tanya jawab, bahkan seorang peserta menyatakan termotivasi untuk mulai Menyusun modul dan berharap modulnya bisa digunakan dalam proses pembelajaran di berbagai sekolah. Hambatan dari kegiatan ini berupa keterbatasan waktu pelaksanaan sehingga peserta kurang maksimal dalam menyusun modul.

\section{SIMPULAN}

Kegiatan pengabdian pendampingan penyusunan modul ini memberikan dampak yang baik bagi para guru di SMA N 4 Purwokerto. Para guru dapat menyusun modul yang sistematis dan dapat digunakan sebagai bahan ajar dalam pembelajaran. Dengan demikian, siswa juga akan mendapat materi dengan baik sehingga lebih mudah untuk memahami pelajaran. Selain itu, kegiatan pengabdian ini juga dapat membantu guru untuk mengembangkan kemampuan menulisnya. Kegiatan yang akan dilaksanakan untuk tahapan berikutnya meliputi pelaksanaan evaluasi dari kegiatan tersebut. Hal yang belum dilaksanakan adalah evaluasi dari hasil modul yang sudah dihasilkan oleh guru-guru yang mengikuti pelatihan. Selain itu, juga pencetakan modul yang sudah mendapatkan pembimbingan oleh tim pengabdi. 
Pelatihan Penyusunan Modul Guna Meningkatkan Kualitas Literasi Bagi Guru SMA

Negeri 4 Purwokerto

\section{UCAPAN TERIMA KASIH}

Tim pengabdian mengucapkan terima kasih kepada Lembaga Penelitian dan Pengabdian Masyarakat yang telah membiayai kegiatan pengabdian ini dalam kegiatan pengabdian dengan skema penerapan IPTEKS dengan judul "Pelatihan Penyusunan Modul Guna Meningkatkan Kualitas Literasi Bagi Guru SMA Negeri 4 Purwokerto".

\section{DAFTAR PUSTAKA}

[1] Y. Zhao, Catching Up or Leading the Way. Alexandria: ASCD, 2009.

[2] Y. L. O. Siahaan and R. I. Meilani, "Sistem Kompensasi dan Kepuasan Kerja Guru Tidak Tetap di Sebuah SMK Swasta di Indonesia," J. Pendidik. Manaj. Perkantoran, vol. 4, no. 2, p. $141,2019$.

[3] L. . Snyder and M. . Snyder, "Teaching Critical Thinking and Problem Solving Skills," Delta Pi Epselon J., vol. 50, no. 2, pp. 90-99, 2008.

[4] M. Mawardi, "Rambu-rambu Penyusunan Skala Sikap Model Likert untuk Mengukur Sikap Siswa," Sch. J. Pendidik. dan Kebud., vol. 9, no. 3, pp. 292-304, 2019.

[5] I. Magdalena, R. O. Prabandani, E. S. Rini, M. A. Fitriani, and A. A. Putri, "Analisis pengembangan bahan ajar," Nusant. J. Pendidik. dan Ilmu Sos., vol. 2, no. 2, pp. 170-187, 2020.

[6] I. Anwar, Pengembangan Bahan Ajar. Bahan Kuliah Online. Direktori UPI. Bandung. Direktorat Pembinaan Sekolah Menengah Kejuruan Departemen Pendidikan Nasional. 2008. Teknik Penyusunan Modul. Seri Bahan Bimbingan Teknis Implementasi. Jakarta: Direktorat Jenderal Manajemen Pendidikan Dasar dan Menengah, 2010.

[7] I. N. . Sutrisna, L. P. . Damayanthi, K. . Artana, and D. . Wahyuni, "Pengembangan Modul Ajar Pembuatan Storyboard Berbasis Metode Pembelajaran Drill and Practice Untuk Siswa Kelas XI Program Keahlian Multimedia di SMK Negeri 1 Sawan," Kumpul. Artik. Mhs. Pendidik. Tek. Inform., vol. 3, no. 7, pp. 424-428, 2014.

[8] A. Zaini, "Optimalisasi Ketercapaian Standar Proses Pembelajaran untuk Meningkatkan Mutu Pendidikan di SMPN Pamekasan," J. Pendidik., vol. 1, no. 1, pp. 1-8, 2013.

[9] G. Nurjaya, "Pengembangan Bahan Ajar Metode Pembelajaran Bahasa dan Sastra Indonesia Berbasis Pembelajaran Kooperatif Jigsaw untuk Meningkatkan Pemahaman dan Kemampuan Aplikatif Mahasiswa," J. Pendidik. Indones., vol. 1, no. 2, pp. 102-111, 2012.

[10] U. . Nasoah, M. Izuan, and Nazipah, "Model Addie dalam Proses Reka Bentuk Modul Pengajaran: Bahasa Arab Tujuan Khas di Universiti Sains Islam Malaysia Sebagai Contoh," in Proceedings of the International Seminar on Language Teaching ISeLT 2015, 2015.

[11] M. Warif, "Strategi Guru Kelas dalam Menghadapi Peserta Didik yang Malas Belajar," TARBAWI J. Pendidik. Agama Islam, vol. 4, no. 01, pp. 38-55, 2019.

[12] Depdiknas, “Teknik Penyusunan Modul,” pp. 1-14, 2008.

[13] I. Harta, S. Tenggara, and P. Kartasura, "Pengembangan Modul Pembelajaran untuk Meningkatkan Pemahaman Konsep dan Minat SMP," Pengemb. Modul Pembelajaran untuk Meningkat. Pemahaman Konsep dan Minat SMP, vol. 9, no. 2, pp. 161-174, 2014.

[14] S. Sungkono, "Pengembangan Dan Pemanfaatan Bahan Ajar Modul Dalam Proses Pembelajaran," Maj. Ilm. Pembelajaran, vol. 5, no. 1, 2009.

[15] A. Rusilowati, "Pengembangan Instrumen Non Tes," Semin. Nas. Eval. Pendidik., no. Depdiknas 2003, pp. 7-21, 2013. 